\title{
Aneta Kaźmierska-Patrzyczna
}

Uniwersytet Łódzki, Polska

apatrzyczna@wpia.uni.lodz.pl

ORCID: 0000-0002-0515-1436

\section{Recenzja monografii Anny Barczak, Kontrola podmiotów korzystających ze środowiska, Wolters Kluwer, Warszawa 2020}

\author{
Review of the monograph by A. Barczak, Kontrola podmiotów korzystajacych \\ ze środowiska [Control of entities using the environment], Wolters Kluwer, Warsaw 2020
}

Wybór tematu recenzowanej monografii należy ocenić z uznaniem. Mieści się bowiem w nurcie badawczym szeroko ujmowanego prawa ochrony środowiska, które jest przedmiotem ciągłego zainteresowania ze strony przedstawicieli nauki prawa, w tym zwłaszcza na płaszczyźnie dogmatycznoprawnej. Jednakże tytułowa problematyka jest w zasadzie nowym obszarem badawczym, gdyż do tej pory analiza polskiej regulacji prawnej dotyczącej instytucji kontroli przestrzegania przepisów ochrony środowiska (tzw. kontroli środowiskowej) nie była przedmiotem szczegółowego opracowania o charakterze monograficznym. Autorka podjęła się zadania niezwykle trudnego, a jednocześnie bardzo istotnego dla teorii i praktyki prawa ochrony środowiska. Określając ramy badanego zagadnienia, wskazała, iż w kontekście wykonywania zadań w zakresie ochrony środowiska przez organy administracji kwestie związane $\mathrm{z}$ kontrolą można przedstawić $\mathrm{w}$ dwóch ujęciach. W ramach jednego z nich, które jest przedmiotem prowadzonych w recenzowanej monografii badań, kontrola jest treścią określonego zadania kontrolnego, dotyczącego badania działania podmiotu kontrolowanego. Ponadto może być ona również ujmowana jako kontrola działalności danego organu co do wykonywania nałożonych zadań ochronnych, którego to aspektu w opracowaniu Autorka jednak nie porusza.

Badany w pracy zasadniczy problem tyczący się analizy kontroli podmiotów korzystających ze środowiska został prawidłowo określony pod kątem zasięgu i wnikliwości poruszanych zagadnień. Temat publikacji nawiązuje do dotychczasowych osiągnięć i potrzeb nauki i praktyki w dziedzinie szeroko ujmowanego prawa ochrony środowiska. W związku z powyższym dokonany przez Autorkę wybór tematyki badawczej, a także sposób jej ujęcia należy uznać za interesujący i merytorycznie uzasadniony. Sformułowanie samego tytułu opracowania odzwierciedla szerokie oraz kompleksowe ujęcie poruszanych w pracy kwestii związanych z kontrolą przestrzegania przepisów ochrony środowiska. Jak słusznie wskazuje Autorka, należy zdawać sobie sprawę z tego, że kompetencje uczestników proce- 
su kontrolnego w zakresie ochrony środowiska daleko wykraczają poza wiedzę prawniczą i proces ten wymaga wiedzy i doświadczenia z obszaru innych dziedzin wchodzących w interdyscyplinarną naukę prawa ochrony środowiska. Spełnienie warunków jakości analizowanego prawa wymaga także istnienia odpowiedniego zaplecza naukowo-badawczego i doradczego, odpowiednich programów, metod nauczania i doskonalenia kadr oraz społeczeństwa ekologicznego aktywnie uczestniczącego w tych procesach. Dlatego też wyróżnia się wielu uczestników postępowania kontrolnego w zakresie kontroli środowiskowej.

W recenzowanej monografii uwzględniono wielopłaszczyznową metodę badawczą. Przede wszystkim została zastosowana metoda dogmatycznoprawna polegająca na kompleksowej i wszechstronnej analizie polskiego materiału normatywnego, a także na badaniu i ocenie powstałych na tym tle poglądów doktryny, szczególnie prawa ochrony środowiska, ale również prawa administracyjnego i prawa gospodarczego oraz orzecznictwa (przede wszystkim sądów administracyjnych). Z uwagi na to, że do tej pory brak jest jednolitych unormowań w zakresie kontroli przestrzegania przepisów ochrony środowiska w prawie międzynarodowym i unijnym, rozważania prowadzone w niniejszej monografii dotyczą głównie prawa polskiego z odwołaniem, w niektórych przypadkach, do prawa unijnego. Analizie zostały poddane polskie akty normatywne z zakresu badanej nauki, w tym przepisy ustrojowe, materialne i procesowe. Dla pełniejszego zobrazowania przedstawianej problematyki Autorka przeprowadziła rozważania, opierając się na regulacjach zawartych zarówno w aktach prawnych rangi ustawowej, jak i aktach o charakterze wykonawczym.

Monografia Anny Barczak ma bardzo przejrzysty i logicznie uporządkowany układ treściowy, ujmujący tytułową problematykę w pięciu rozdziałach merytorycznych oraz wstępie i zakończeniu. Każdy rozdział poprzedzony jest uwagami wstępnymi i zakończony podsumowaniem, co niewątpliwie stworzyło pewną całość badanej w każdym rozdziale tematyki, która dzięki temu zabiegowi jest czytelniejsza i przejrzystsza. Na szczególne wyróżnienie zasługuje praktyczny walor recenzowanej monografii, który jest charakterystyczny dla wielu publikacji Autorki ${ }^{1}$. W opracowaniu zawarto bowiem listę pytań kontrolnych (tzw. checklistę), która pozwala na szybkie zbadanie zgodności działań podmiotów korzystających ze środowiska z procedurami i środowiskowymi przepisami prawnymi. $\mathrm{W}$ rozdziale pierwszym, który ma charakter wprowadzający, wyjaśniono istotę kontroli środowiskowej, jej pojęcie, rodzaje i kryteria, zakres podmiotowy i przedmiotowy, cechy charakterystyczne, standaryzację dobrej kontroli środowiskowej, a także wskazano zasady ogólne prawa ochrony środowiska jako podstawę zasad ogólnych kontroli środowiskowej. W rozdziale drugim przedstawiono kontrolę środowiskową w ujęciu podmiotowym. Autorka scharakteryzowała wybrane organy kontrolne, dokonując wnikliwej analizy ich ustroju i środowiskowych zadań kontrolnych, przy czym szczególną uwagę poświęciła Inspekcji Ochrony Środowiska (IOŚ). W rozdziale trzecim omówiono przepisy regulujące przebieg kontroli środowiskowej, z uwagi jednak na dość szeroki zakres podmiotowy tytu-

1 Zob. m.in. Barczak, A. et al., Oceny oddziaływania na środowisko w prawie polskim. Ze wzorami dokumentów i schematami. Warszawa 2018; Barczak, A. i Ogonowska, A., Uchwały rady gminy w zakresie ochrony środowiska i przyrody. Wzory z komentarzem. Warszawa 2019. 
łowego zagadnienia rozważania w znacznej mierze zostały przez Autorkę ograniczone do przebiegu kontroli sprawowanej przez IOŚ. W rozdziale czwartym zawarto kwestie związane z systemem ekozarządzania i audytu środowiskowego (EMAS). Zwrócono uwagę na jego istotę, zakres podmiotowy i przedmiotowy oraz zasady funkcjonowania i wdrażania systemu, a także rolę organów administracji i weryfikatorów środowiskowych w tym zakresie. Ostatni, piąty rozdział przedstawia prawa i obowiązki podmiotów korzystających ze środowiska w toku prowadzonego postępowania kontrolnego i po jego zakończeniu.

Wybór powyższych zagadnień nie jest przypadkowy, gdyż szczegółowa ich analiza w pełni pozwoliła Autorce odpowiedzieć na postawione pytania badawcze: czy organizacja podmiotów kontrolujących i wyposażenie ich w odpowiednie kontrolne środki prawne wpływają na sprawność kontroli środowiskowej; czy istniejące regulacje prawne są wystarczające w zakresie kontroli środowiskowej; czy stosowane przez organy kontrolujące instrumenty prawne nie zmniejszają konkurencyjności uczciwych przedsiębiorców (zob. s. 14). Z przeprowadzonych w monografii rozważań wynika, że teoretycznie przepisy ustrojowe, materialne i proceduralne przewidują odpowiednie struktury, mechanizmy i środki prawne przeznaczone do realizacji zadań kontrolnych. W ocenie Anny Barczak „nie ma większego sensu rozbudowywanie organów kontroli, gdyż ich rozrost nie jest zjawiskiem ani pozytywnym, ani bezpiecznym" (zob. s. 233). Autorka podkreśla również duże znaczenie regulacji dotyczących systemu ekozarządzania i audytu (EMAS), wymuszającego zaangażowanie organizacji w zakresie przestrzegania przepisów ochrony środowiska. Słusznie zauważa, że system ten odciąża działania administracji publicznej, jednocześnie je uzupełniając. Jest to instytucja mobilniejsza i elastyczniejsza niż kontrolny system administracji publicznej. Jednakże wyraźnie zaznacza, że stosowanie obowiązujących przepisów napotyka duże trudności w praktyce. Wśród nich Autorka wskazuje na braki kadrowe, organizacyjne i techniczne organów kontrolnych, które są powodem niewystarczającej skuteczności tychże organów w ograniczaniu i zwalczaniu nielegalnych działań.

O rzetelnym i wnikliwym opracowaniu tematu świadczą również odpowiednio dobrane materiały źródłowe. Szczególną uwagę zwraca bogata bibliografia, która liczy 10 stron, co pozwala na stwierdzenie, że Autorka dotarła do wszystkich istotnych publikacji poruszających tematykę pracy. Przeanalizowała także wszystkie akty prawne $\mathrm{z}$ tego zakresu, wykorzystała też orzecznictwo i źródła internetowe.

Recenzowana monografia została napisana komunikatywnym językiem. Autorka wykazała się umiejętnością syntetycznego ujmowania omawianej materii i przekonująco udowodniła, że potrafi panować nad ogromem opracowywanego materiału. Jej rozważania cechują dojrzałość i wyważenie w formułowaniu ocen. Na podkreślenie zasługują również sumienność i pasja badawcza Autorki.

Biorąc powyższe pod uwagę, można z pełnym przekonaniem stwierdzić, że recenzowana monografia, $\mathrm{z}$ uwagi na przedmiot i zakres prowadzonych w niej rozważań, prezentuje oryginalną koncepcję instytucji kontroli przestrzegania przepisów ochrony środowiska, z uwagi zaś na poziom i jakość zawartych treści praca ta powinna stanowić obowiązkową pozycję literatury dla prawników specjalizujących się w ochronie interesów podmiotów korzystających ze środowiska, pracowników Inspekcji Ochrony Środowiska, Wód Polskich, 
Państwowej Straży Pożarnej, dyrektorów ochrony środowiska oraz organów lokalnych kontrolujących te podmioty, a także przedsiębiorców i sędziów sądów administracyjnych. Niezaprzeczalnie jest również cennym źródłem wiedzy dla przedstawicieli nauki oraz studentów prawa i administracji. 